\title{
Degradation Behavior of Nano-Glue Adhesive due to Historical Textiles Conservation Process
}

\author{
H. E. Ahmed ${ }^{1}$, W.S. Mohamed ${ }^{2 *}$, H. Saad ${ }^{3}$, H.E. Nasr ${ }^{2}$, M.Morsy ${ }^{4}$ \\ N. Mahmoud ${ }^{3}$ \\ ${ }^{1}$ Conservation Dept., Faculty of Archaeology, Cairo University, Egypt. ${ }^{2}$ Polymer \\ and Pigment Dept, Chemical Industry Division, National Research Centre, \\ Egypt. ${ }^{3}$ Conservation Dept., Faculty of Archaeology, Fayoume University, Egypt. \\ ${ }^{4}$ Textiles Metrology, National Institute of Standards, Egypt.
}
$\mathbf{F}$ RAGILE textiles in museums need to consolidate by natural adhesives such as animal glue due to conservation process. Sometimes the animal glue becomes shrunk, cracked, and rigid after long term. The article is aimed to study using Nano animal glue adhesive in historic textiles conservation field in order to consolidate the fragile textiles. For this, an extensive experimental work was done to study the ageing behavior of Nano animal glue after artificial ageing process. Firstly, Wool fabric dyed with natural dyes such as madder and safflower dye mordanted with different mordents to similarity for the historical textiles. The wool dyed fabrics were coated with animal glue adhesive and nano animal glue adhesive. The treated wool fabrics were aged by accelerated thermal ageing for different time.

A comparative study was done in order to characterize changes in properties as well as the physical and chemical degradation of treated wool fabrics before and after thermal ageing. Different type of analysis methods such SEM , FTIR, the colors are given in Commission internationale de l'éclairage (CIE L*a*b*) coordinates and mechanical properties. This article presents interesting results concerning the effect of ageing on characterization of nano glue adhesive furthermore for treated wool fabrics.

Keywords: Nano glue, Adhesive, Textiles, Ageing, CIE L*a*b*, SEM, XRD, FTIR.

\section{Introduction}

Over the past forty years, conservators are using adhesive techniques for consolidation of the fragile historic textiles as shown in Fig.1. These experiences have provided a good knowledge of the failures and successes of these adhesives treatments. By another hand, the frame of using adhesive in textile conservation treatments, it covers the following: firstly, treatments by using adhesive are only suitable for deteriorated textiles and degraded silks; secondly, adhesives should not penetrate into historic textiles. So, adhesives must be applied as sparingly as possible [1-7]. Due to conservation procedure, animal glue adhesive can be found on historic textiles as consolidation step, or when the historic textiles to a solid surface adhered. It is noticed by the aged condition animal glue paste may be present in shrunk, brittle form, cracked, rigid. Also, it does not provide enough and good adhesion for supporting the historic textiles $[8,9]$. Natural the animal glues polymers are derived from collagen. Collagen is major structural protein of skins, tissue, bones and cartilage. The animal glue is characterized by the properties of different chemical and physical according to the source and methods of preparation. In the manufacture of artifacts and objects, some knowledge exists that the animal glues are more suitable for specific purposes [10-12].

Some researchers such as Osman, et al.; Garside, et al.; Kim, et al.; Kim and Wyeth; and Leene, et al., studied the effect of artificial aging such as the thermal and light on treated textiles by adhesives. They evaluated the changes in the optical, chemical and mechanical characterization. The result of this research has found that the accelerated aging make a deterioration of aged fabrics [13-15]. 

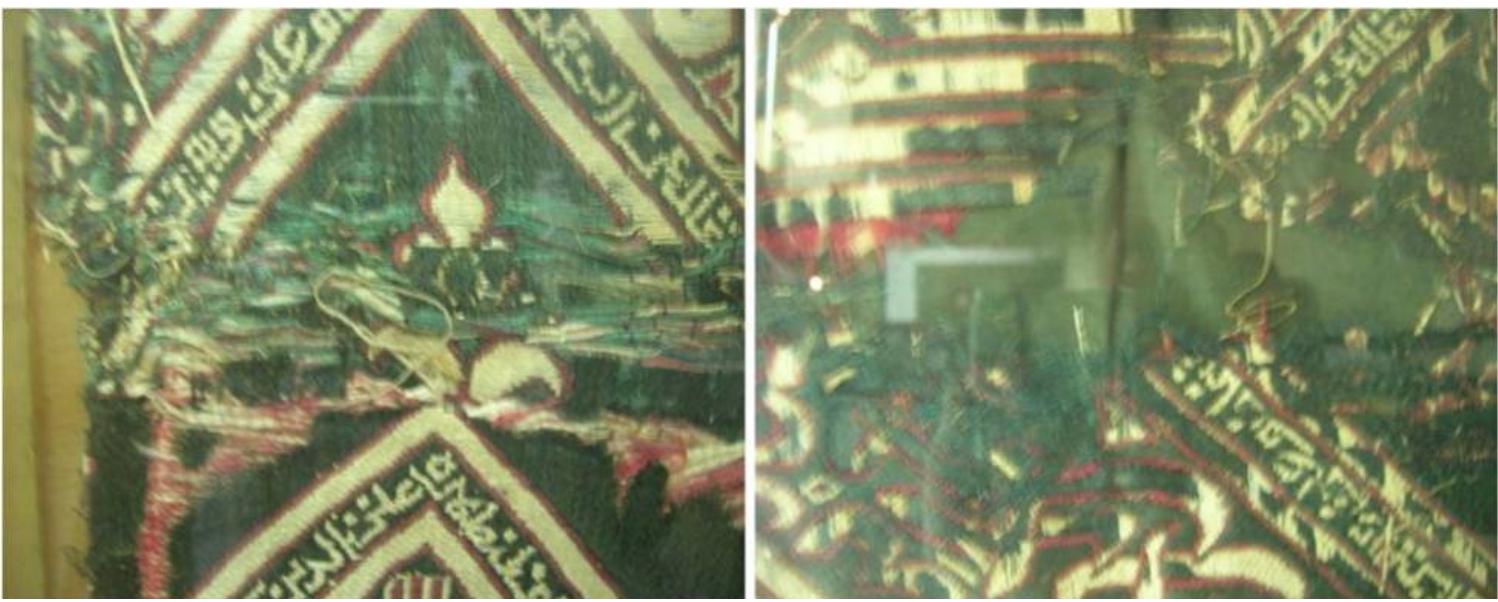

Fig. 1. The fragile historic textile in Faculty of Archeology museum - the Islamic art section-, Cairo University. One can see the object condition and why it needs to conserve and consolidate by adhesive.

\section{Materials and Methods}

\section{Materials}

Gelatin type A from porcine skin (175 Bloom), glutaraldehyde grade I $25 \%$ aqueous solution was obtained from Merck Darmstadt, Germany. Acetone, ethyl alcohol and acetonitrile were purchased from Alnasr Co. (Egypt).

\section{Methods}

Dyeing

Extraction of dye: The dyeing with madder or safflower dye $10 \%(\mathrm{w} / \mathrm{v})$ ware carried out according to to the following steps:

- The first step is grinding the natural dye to be a fine powder.

- $\quad$ Soaking the natural dyes powder in the distilled water for $12 \mathrm{hr}$ in order to extract the color from the dyes powder.

- $\quad$ Then with the stirring heating the extract to the boiling temperature degree for $2 \mathrm{hr}$. It is noticed must be adding water to compensate the evaporated water during the heating process.

- After that allowing to the extract to be cooled and then filtering the extract many times in order to get a clear solution of colored.

Dyeing procedure: Dyeing procedure of wool fabrics was done according to the exhaustion method [16] a liquor ratio of dyeing bath (LR) of 1:20 (for each $1 \mathrm{~g}$ of natural dye the bath volume is $20 \mathrm{ml}$ ). The dyeing procedure was performed in a beaker. In the step of dyeing procedure some mordants, such as alum; Copper sulfate and Iron III chloride were added in concentration $(50 \mathrm{~g}$
$\mathrm{L}^{-1}$ ) to give a final dye bath concentration of 2.5 $\mathrm{g} \mathrm{L}^{-1}$ or $5 \mathrm{~g} \mathrm{~L}^{-1}$ mordant. After finishing the dyeing procedure, removing the unfixed dyestuff was done by rinsing the dyed samples three times in cold water baths ( for $5 \mathrm{~min}$ at room temperature, LR 1:20) [17-19].

\section{Samples preparation}

Wool fabric samples were cut into $25 \times 5 \mathrm{~cm}$ (length $\mathrm{x}$ width) in warp test specimens direction. The warp strips were prepared by reveling away the yarns on each side forming $1.5 \mathrm{~cm}$ wide strips with a $2.5 \mathrm{~mm}$ fringe down each side. In this test five samples were used for each test.

\section{Preparation of nano-animal glue}

Gelatin nanoparticles were prepared by a two-step desolvation method, previously described by Coester et al [20]. In brief: $1.25 \mathrm{~g}$ gelatin was dissolved in $25 \mathrm{~mL}$ distilled water under constant heating temperature range at $27^{\circ} \mathrm{C} .25 \mathrm{~mL}$ acetone was added to the gelatin solution as a desolvating agent to precipitate the high molecular weight (HMW) gelatin. The supernatant was discarded and the HMW gelatin re-dissolved by adding $25 \mathrm{~mL}$ distilled water and stirring at $600 \mathrm{rpm}$ under constant heating. The $\mathrm{pH}$ of the gelatin solution was adjusted to values between 4.0 and 5.5 . Acetone $(75 \mathrm{~mL})$ was added drop-wise to form nanoparticles. At the end of the process, $250 \mu \mathrm{L}$ of $25 \%$ glutaraldehyde solution was used for preparing nanoparticles as a crosslinking agent, and stirred for $12 \mathrm{~h}$ at $600 \mathrm{rpm}$. The remaining organic solvent was evaporated using a rotary evaporator. Figure 2 shows TEM images of the prepared nano-animal glue. 


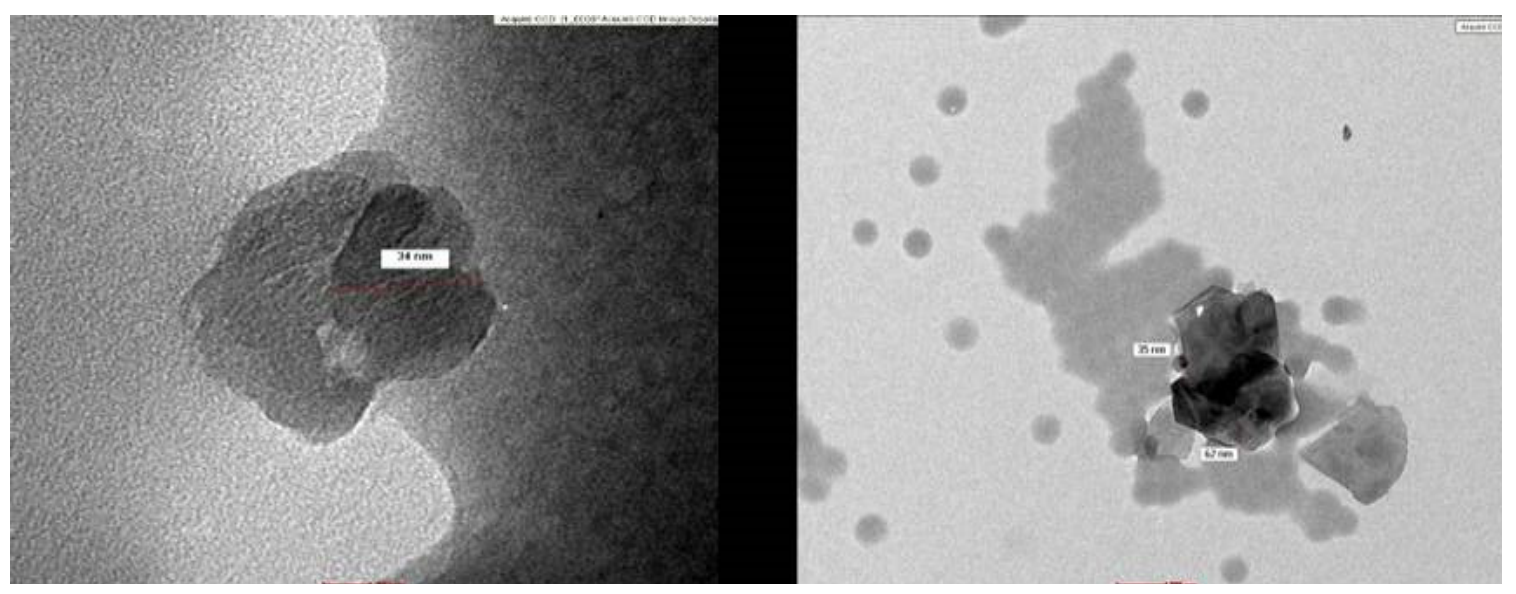

Fig. 2. (A, B). TEM images of the prepared nano-animal glue using two different magnification. From the images, it is obvious that, the nanoparticles were spherical and well dispersed, with an average size of about 34-62 nm.

\section{Treatments}

Dyed wool fabrics were treated with the animal glue adhesives and Nano animal glue adhesives in $5 \%$ concentration according to the standard method of conservation [8-11].

\section{Accelerated ageing}

Feller presented possible thermal testing times for different classes of thermal stability based on the deterioration rate that will double for a rise of $100^{\circ} \mathrm{C}$ and on the statement that heating textiles or paper for $72 \mathrm{~h}$ ( 3 days $)$ at $100^{\circ} \mathrm{C}$ is equivalent around 25 years of natural ageing under normal condition of ageing. Wool dyeing fabrics were hanged in a temperature-controlled oven "Herous-Germany" on special frames. The dyed wool samples were thermally aged at $100{ }^{\circ} \mathrm{C}$ for different times such as 3,6, days [21-23]

\section{Examinations and analysis}

Morphological study of wool samples: The surface morphology of the dyed wool fabrics (untreated and treated by glue adhesive or nano glue adhesive) ware investigated by using Scanning Electron Microscope module (Quanta 200 ESEM FEG from FEI). Very small samples were cut and taken from the treated and untreated wool dyed fabric from different areas. Then the samples were investigated under SEM in order to show any changes of fibers resulting from the damage by thermal ageing [24-25].

Morphological study of glue and nano glue: The particle size of the prepared nano- animal glue was measured using transmission electron microscope (TEM), where the TEM images were obtained by JEM-1230-electron microscopy operat- ed at $60 \mathrm{kV}$. Before taking a TEM image, the sample was diluted at least 10 times by water. A drop of well dispersed diluted sample was placed onto a copper grid (200 mesh and covered with a carbon membrane) and dried at ambient temperature. A drop of phosphotungstic acid $(0.4 \%)$ as a stain was deposited over the dried sample [26].

Color measurement: The CIE-Lab values of dyed wool fabrics (untreated and treated by glue adhesive or nano glue adhesive) were measured by using a double beam Optimatch spectrophotometer (Datacolor international Spectraflash SF450-UK). When the color in different formulae desirable to express color specifications in terms of such correlates. The colors that given in CIE Lab coordinates are, L value corresponding to the brightness $(100=$ white, and $0=$ black), while $\mathrm{a}^{*}$ value to the red-green coordinate $($ positive sign $=$ red, and negative sign $=$ green), and $b^{*}$ value to the yellow-blue coordinate (positive sign $=$ yellow, and negative sign $=$ blue $)$. The total difference of color $\Delta \mathrm{E}^{*}$ between two color stimuli $\Delta \mathrm{E}^{*}=\left\{\left(\Delta \mathrm{L}^{*}\right)^{2}+\left(\Delta \mathrm{a}^{*}\right)^{2}+\left(\Delta \mathrm{b}^{*}\right)^{2}\right\} 1 / 2[27-$ 29].

Tensile strength and elongation: Elongation and tensile strength test of the dyed wool fabrics (untreated and treated by glue adhesive or nano glue adhesive) before and after thermal ageing were measured by using a Lloyd Tensile Testing Machine Type T5K. Elongation and tensile strength test were done in metrology lab according to ASTM (2000), D 5035-95. The spacing of initial jaw was $50 \mathrm{~mm}$ and the speed of the test was $25 \mathrm{~mm} / \mathrm{min}$, at temperature 23 C, and R.H. 65\% [30].

Fourier transform infrared spectral analysis Egypt.J.Chem. 60, No. 6 (2017) 


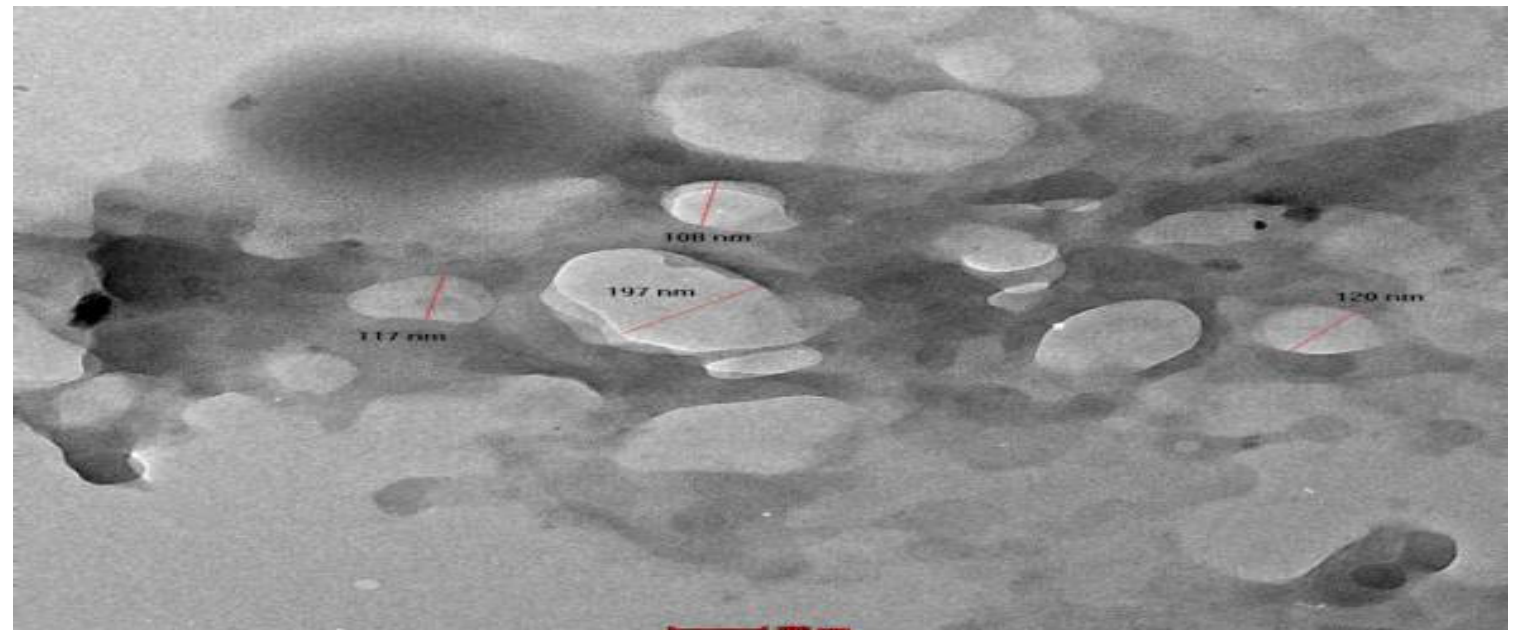

Fig. 3. The TEM images of the normal animal glue. From the figure, it is obvious that, the glue particles have no regular shape and also were not regularly dispersed, with particle size reached to $197 \mathrm{~nm}$.

(FTIR): The chemical structural changes that occurr in dyed wool fabrics (untreated and treated by glue adhesive or nano glue adhesive) before and after thermal ageing were measured by using FTIR. Vibrational bands of wool fabrics that appear in the infrared spectra will provide more information about the chemical functional groups of a wool sample. This information will lead to a general characterization of the treated and untreated wool fabrics. Also this bands will help in the identification of specific compounds [31-32]. FTIR analysis of wool fabrics was carried out by using BRUKER - FTIR- TENSOR.

\section{$\underline{\text { Results and Discussions }}$}

The effect of ageing on mechanical parameters of treated samples

Strength and elongation of coated wool fabrics by animal glue and Nano animal glue before and after ageing are presented in Tables 1 and 2. It is noticed that animal glue and Nano glue adhesive increase the tensile strength of treated wool samples. For examples wool dyed by safflower mordanted by alum show increase in the tensile strength from 25.13 to 27.72 after applying animal glue adhesive. In other words, the using animal glue improves the strength of treated wool fabrics. It is clear that the treated wool fabrics with animal glue adhesive became more rigid as the elongation of the sample is decreased. While the Nano glue adhesive improves both of the strength and elongation of coated wool fabrics. While the treated wool fabrics with Nano glue adhesive more elastic as the elongation of the wool sample is increased. The results indicate that the percent of the increase in the tensile strength depends on type of the adhesives.

The effect of ageing on mechanical parameters of treated samples

Table 1 shows that there are slightly decrease in strength and elongation of coated wool fabrics with animal glue adhesive after thermal ageing. While Table 2 shows that there are slightly increase in tensile strength and elongation of treated wool fabrics with Nano glue adhesive after thermal ageing. By comparing different results in Tables 1 and 2 of both strength and elongation of treated wool fabrics before and after thermal ageing it is noticed that the most effective adhesive is Nano glue adhesive. It is clear that Nano glue adhesive is suitable for conservation of wool fabrics more than animal glue adhesive.

The effect of ageing on optical parameters of treated samples

Color change such as $\mathrm{K} / \mathrm{S}$ and Lab value of treated samples by animal glue and nano animal glue before and after thermal ageing are presented in Tables 3 and 4. From Tables 3 and 4 it is observed that there is decrease of treated samples by animal glue in the brightness index L after ageing. For example wool dyed by safflower mordanted by alum show decrease in the brightness, index L from 66.06 to 65.61 . While there is an increase of treated samples in the value to red-green, coordinate. One can see that wool dyed by safflower mordanted by alum show very slight increase in the value to red-green coordinate from 16.5 to 16.75 . While there is an increase in $b^{*}$ value yellow-blue coordinate of treated 
samples after ageing. For example, wool dyed by safflower mordanted by alum show increase in value yellow-blue coordinates from 32.9 to 34.8 . By another hand, there are no noticeable changes in the color of treated wool textile by nano glue adhesive samples before and after the thermal ageing.

Furthermore, Tables 3 and 4 show the different color change $\Delta \mathrm{E}$ of the wool fabrics dyed with safflower or madder mordanted with different type of mordents that treated with animal glue or nano glue before and after ageing. The tables showing increasing of $\Delta \mathrm{E}$ when increasing the time of ageing for all the samples. Also, one can see that the total color change different of treated wool with nano glue after ageing less than treated wool fabrics with animal glue after ageing. This is mean that the nano glue is more stable than

TABLE 1. The elongation and force of samples after applying Glue and ageing.

\begin{tabular}{|c|c|c|c|c|c|c|c|c|}
\hline \multirow{2}{*}{$\begin{array}{c}\text { Wool } \\
\text { Samples }\end{array}$} & \multicolumn{2}{|c|}{ Samples after dyeing } & \multicolumn{2}{|c|}{$\begin{array}{c}\text { Samples after applying } \\
\text { Glue }\end{array}$} & \multicolumn{2}{|c|}{$\begin{array}{l}\text { Samples }+ \text { Glue }+ \\
\text { ageing } 100 \mathrm{C} \text { for } 72 \mathrm{~h}\end{array}$} & \multicolumn{2}{|c|}{$\begin{array}{c}\text { Samples + Glue + ageing } \\
\text { 100C for } 144 \mathrm{~h}\end{array}$} \\
\hline & Elongation \% & $\begin{array}{c}\text { Max Force } \\
\mathbf{N}\end{array}$ & $\begin{array}{c}\text { Elongation } \\
\%\end{array}$ & $\begin{array}{c}\text { Max } \\
\text { Force N }\end{array}$ & $\begin{array}{c}\text { Elongation } \\
\%\end{array}$ & $\begin{array}{c}\text { Max Force } \\
\mathbf{N}\end{array}$ & Elongation \% & $\begin{array}{c}\text { Max Force } \\
\mathbf{N}\end{array}$ \\
\hline Saff + Alum & 27.57 & 25.13 & 25.85 & 27.72 & 25.25 & 28.43 & 24.62 & 27.52 \\
\hline Saff+ Iron & 36.27 & 24.21 & 23.95 & 26.74 & 23.63 & 26.25 & 24.05 & 26.70 \\
\hline $\mathrm{Saffl}+\mathrm{Cu}$ & 28.78 & 24.36 & 24.18 & 26.66 & 22.17 & 26.89 & 22.73 & 27.42 \\
\hline Saff without & 31.88 & 23.42 & 23.03 & 26.77 & 23.51 & 26.09 & 23.03 & 25.66 \\
\hline Mad+ Alum & 36.45 & 24.53 & 28.92 & 28.61 & 25.84 & 27.65 & 24.53 & 26.83 \\
\hline Mad+ Iron & 35.25 & 24.35 & 29.85 & 27.71 & 24.68 & 28.01 & 23.00 & 27.87 \\
\hline $\mathrm{Mad}+\mathrm{Cu}$ & 32.23 & 24.46 & 26.83 & 28.13 & 23.33 & 28.46 & 25.39 & 28.73 \\
\hline Mad without & 23.59 & 23.59 & 27.33 & 27.98 & 19.37 & 27.99 & 23.36 & 28.99 \\
\hline
\end{tabular}

TABLE 2. The elongation and force of samples after applying Nano Glue and ageing.

\begin{tabular}{|c|c|c|c|c|c|c|c|c|}
\hline \multirow{2}{*}{$\begin{array}{c}\text { Wool } \\
\text { Samples }\end{array}$} & \multicolumn{2}{|c|}{ Samples after dyeing } & \multicolumn{2}{|c|}{$\begin{array}{c}\text { Samples after applying } \\
\text { nano glue }\end{array}$} & \multicolumn{2}{|c|}{$\begin{array}{c}\text { Samples + Glue + ageing } \\
100 \mathrm{C} \text { for } 72 \mathrm{~h}\end{array}$} & \multicolumn{2}{|c|}{$\begin{array}{l}\text { Samples + Glue + ageing } \\
100 \mathrm{C} \text { for } 144 \mathrm{~h}\end{array}$} \\
\hline & $\begin{array}{c}\text { Elongation } \\
\%\end{array}$ & $\begin{array}{l}\text { Max Force } \\
\quad \mathbf{N}\end{array}$ & $\begin{array}{c}\text { Elongation } \\
\%\end{array}$ & $\begin{array}{c}\text { Max } \\
\text { Force N }\end{array}$ & $\begin{array}{c}\text { Elongation } \\
\%\end{array}$ & $\begin{array}{c}\text { Max Force } \\
\mathbf{N}\end{array}$ & $\begin{array}{c}\text { Elongation } \\
\%\end{array}$ & $\begin{array}{c}\text { Max Force } \\
\mathbf{N}\end{array}$ \\
\hline Saff + Alum & 27.57 & 25.13 & 27.45 & 27.10 & 26.15 & 27.51 & 26.28 & 28.40 \\
\hline Saff+ Iron & 36.27 & 24.21 & 27.64 & 25.92 & 32.35 & 26.81 & 28.75 & 28.51 \\
\hline $\mathrm{Saffl}+\mathrm{Cu}$ & 28.78 & 24.36 & 25.36 & 25.73 & 26.09 & 25.87 & 24.44 & 26.61 \\
\hline $\begin{array}{l}\text { Saff } \\
\text { without }\end{array}$ & 31.88 & 23.42 & 36.60 & 28.08 & 30.81 & 26.96 & 29.57 & 27.26 \\
\hline $\begin{array}{l}\text { Mad }+ \\
\text { Alum }\end{array}$ & 36.45 & 24.53 & 36.64 & 25.98 & 33.73 & 27.07 & 31.36 & 27.18 \\
\hline Mad+ Iron & 35.25 & 24.35 & 41.24 & 26.62 & 37.22 & 27.85 & 34.51 & 27.89 \\
\hline $\mathrm{Mad}+\mathrm{Cu}$ & 32.23 & 24.46 & 31.80 & 26.35 & 33.32 & 26.89 & 30.65 & 26.73 \\
\hline $\begin{array}{l}\text { Mad } \\
\text { without }\end{array}$ & 23.59 & 23.59 & 33.16 & 26.87 & 21.08 & 23.82 & 30.24 & 26.95 \\
\hline
\end{tabular}


TABLE 3. The Lab value of samples after applying Glue and ageing.

\begin{tabular}{|c|c|c|c|c|c|c|c|c|c|c|c|c|}
\hline \multirow{2}{*}{$\begin{array}{c}\text { Wool } \\
\text { Samples }\end{array}$} & \multirow{2}{*}{$\begin{array}{c}\text { Dyed } \\
\text { Sample } \\
\text { K/S }\end{array}$} & \multicolumn{3}{|c|}{$\begin{array}{c}\text { Samples after applying } \\
\text { Glue }\end{array}$} & \multicolumn{4}{|c|}{$\begin{array}{c}\text { Samples + Glue + ageing } \\
100 \mathrm{C} \text { for } 72 \mathrm{~h}\end{array}$} & \multicolumn{4}{|c|}{$\begin{array}{c}\text { Samples + Glue + ageing 100C } \\
\text { for } 144 \mathrm{~h}\end{array}$} \\
\hline & & $\mathbf{L}$ & $\mathbf{a}$ & b & $\mathbf{L}$ & $\mathbf{A}$ & b & $\Delta \mathbf{E}$ & $\mathbf{L}$ & $\mathbf{a}$ & $\mathbf{b}$ & $\Delta \mathbf{E}$ \\
\hline Saff + Alum & 5.0825 & 63.34 & 16.52 & 32.94 & 62.81 & 16.73 & 34.80 & 1.95 & 62.46 & 17.18 & 35.45 & 2.74 \\
\hline Saff + Iron & 11.540 & 49.23 & 8.85 & 27.58 & 47.59 & 9.97 & 28.59 & 2.23 & 48.41 & 9.95 & 28.91 & 2.91 \\
\hline $\mathrm{Saffl}+\mathrm{Cu}$ & 8.3263 & 53.61 & 2.54 & 23.40 & 52.62 & 2.64 & 24.97 & 1.86 & 52.17 & 2.42 & 24.35 & 1.93 \\
\hline Saff without & 5.3056 & 62.94 & 12.31 & 28.78 & 64.13 & 12.25 & 30.29 & 1.92 & 63.07 & 13.35 & 30.70 & 2.19 \\
\hline Mad+ Alum & 5.1361 & 46.64 & 29.27 & 17.67 & 48.35 & 28.54 & 20.29 & 2.15 & 47.39 & 28.53 & 18.83 & 2.75 \\
\hline Mad+ Iron & 10.516 & 38.59 & 13.68 & 19.41 & 37.52 & 12.12 & 18.69 & 2.02 & 37.04 & 12.60 & 18.69 & 2.82 \\
\hline $\mathrm{Mad}+\mathrm{Cu}$ & 6.6974 & 41.61 & 16.76 & 14.58 & 40.39 & 15.22 & 13.83 & 2.10 & 41.15 & 15.65 & 14.13 & 2.28 \\
\hline $\begin{array}{c}\text { Mad } \\
\text { without }\end{array}$ & 5.5348 & 48.47 & 25.64 & 21.03 & 47.34 & 35.74 & 21.30 & 1.17 & 47.26 & 24.64 & 20.60 & 1.63 \\
\hline
\end{tabular}

TABLE 4. The Lab value of samples after applying Nano glue and ageing.

\begin{tabular}{|c|c|c|c|c|c|c|c|c|c|c|c|c|}
\hline \multirow{2}{*}{$\begin{array}{c}\text { Wool } \\
\text { Samples }\end{array}$} & \multirow{2}{*}{$\begin{array}{c}\text { Dyed } \\
\text { Sample } \\
\text { K/S }\end{array}$} & \multicolumn{3}{|c|}{$\begin{array}{c}\text { Samples after } \\
\text { applying Nano glue }\end{array}$} & \multicolumn{4}{|c|}{$\begin{array}{c}\text { Samples }+ \text { Glue }+ \text { ageing } 100 \mathrm{C} \\
\text { for } 72 \mathrm{~h}\end{array}$} & \multicolumn{4}{|c|}{$\begin{array}{l}\text { Samples + Glue + ageing } \\
100 \mathrm{C} \text { for } 144 \mathrm{~h}\end{array}$} \\
\hline & & $\mathbf{L}$ & a & b & $\mathbf{L}$ & a & b & $\Delta \mathbf{E}$ & $\mathbf{L}$ & $\mathbf{a}$ & b & $\Delta \mathbf{E}$ \\
\hline Saff + Alum & 5.0825 & 66.06 & 16.86 & 32.06 & 66.72 & 16.62 & 31.46 & 0.92 & 65.61 & 16.94 & 32.76 & 1.34 \\
\hline Saff+ Iron & 11.540 & 46.99 & 10.52 & 28.27 & 46.00 & 11.31 & 28.88 & 1.41 & 47.03 & 11.50 & 28.46 & 1.88 \\
\hline $\mathrm{Saffl}+\mathrm{Cu}$ & 8.3263 & 54.74 & -1.42 & 27.58 & 53.93 & $0.19-$ & 26.62 & 1.76 & 52.97 & 0.18 & 27.18 & 2.42 \\
\hline $\begin{array}{l}\text { Saff } \\
\text { without }\end{array}$ & 5.3056 & 62.21 & 13.52 & 29.71 & 60.69 & 15.00 & 29.94 & 2.13 & 62.30 & 14.33 & 29.99 & 2.86 \\
\hline $\begin{array}{l}\text { Mad }+ \\
\text { Alum }\end{array}$ & 5.1361 & 48.46 & 28.24 & 17.11 & 47.53 & 29.55 & 18.84 & 2.36 & 46.22 & 30.63 & 19.33 & 3.96 \\
\hline Mad+ Iron & 10.516 & 36.76 & 13.73 & 17.98 & 37.11 & 13.33 & 18.31 & 0.63 & 36.89 & 13.46 & 18.29 & 0.93 \\
\hline $\mathrm{Mad}+\mathrm{Cu}$ & 6.6974 & 40.03 & 17.05 & 15.16 & 39.56 & 15.81 & 14.24 & 1.61 & 39.71 & 16.49 & 15.66 & 1.82 \\
\hline $\begin{array}{l}\text { Mad } \\
\text { without }\end{array}$ & 5.5348 & 45.81 & 26.77 & 19.82 & 46.22 & 26.54 & 20.56 & 0.88 & 45.18 & 27.08 & 20.70 & 1.13 \\
\hline
\end{tabular}

animal glue.

The effect of ageing on fiber morphology of treated samples

SEM show that the fine undamaged flat scales with even, smooth surface and sharp scale edges were visible before treated wool fabrics surface. In addition, after applying the glue or nano glue still the undamaged flat scales are visible nut less than nan treated fabrics. It is noticed by SEM image that the undamaged flat scales of treated wool with nano glue are clearer and visible than wool fabrics treated with animal glue. Figures 4 and 5 show SEM of wool fiber morphology after glue and nano glue adhesive application. One can see that nano glue adhesive do not cause noticeable changes in the fiber morphology of treated samples. One can see that nano glue adhesive do not cause noticeable changes in the fiber morphology of treated samples. It is noticed that the characteristic of fiber morphology surface is too clear. By other words, the results indicate that the coating layer by using nano glue adhesive on the fiber surface is not disappearing the fiber surface and the layer is 


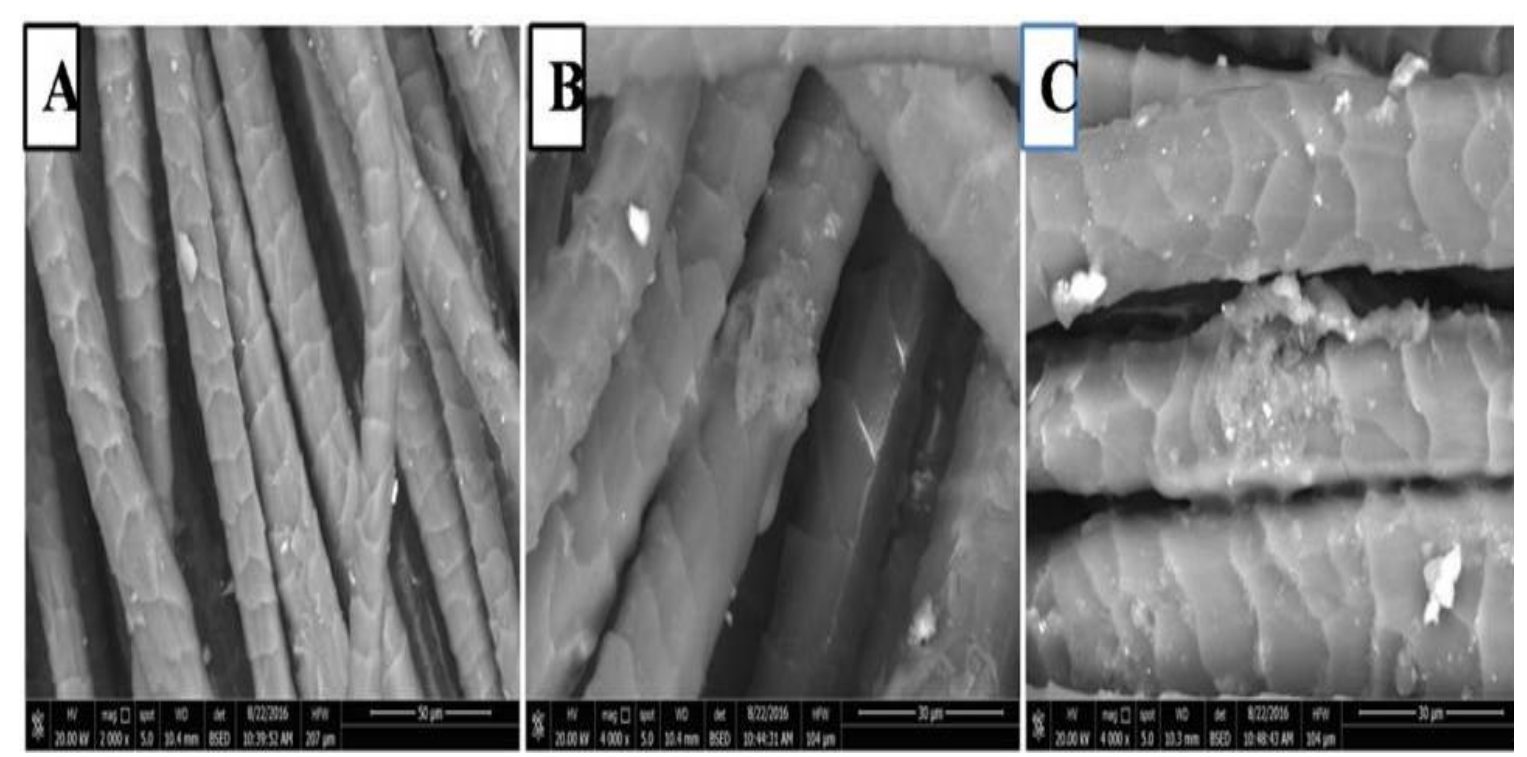

Fig. 4. Silk dyed fabric without treatment (A), silk dyed treated with glue (B) silk dyed treated with glue after ageing for $100 \mathrm{C}$ for $140 \mathrm{~h}(\mathrm{C})$.
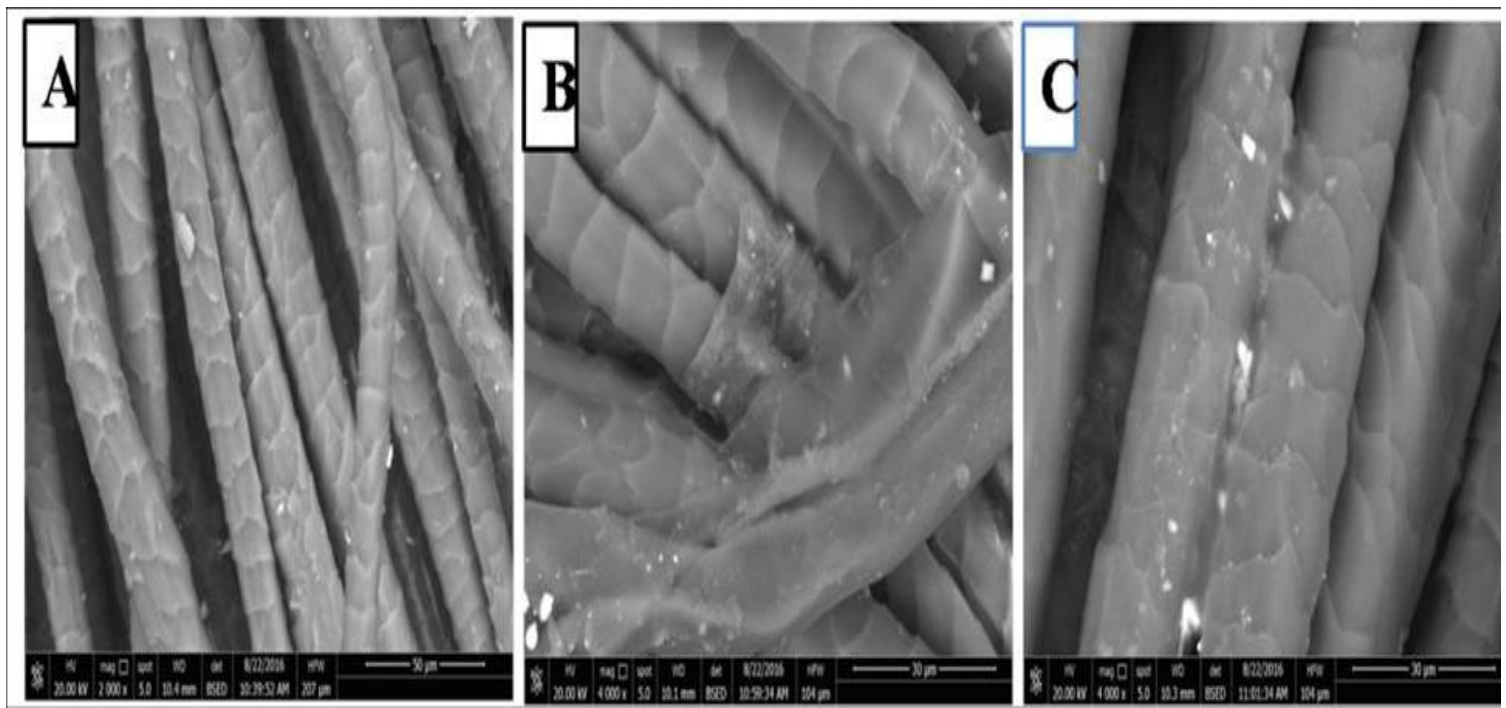

Fig. 5. Silk dyed fabric without treatment (A), silk dyed treated with Nano-Glue (B) silk dyed treated with NanoGlue after ageing for $100 \mathrm{C}$ for $140 \mathrm{~h}(\mathrm{C})$.

very thin.

SEM images show that the changes in morphology of treated fiber by using nano glue adhesive are less than the changes in the surface morphology of treated fiber by using glue adhesive after thermal aging. These results are confirmed that the nano glue adhesive enhances the durability of surface morphology of sample against the thermal deterioration. By comparing SEM images in Fig. 4 and 5. It is clear that Nano glue adhesive is suitable for conservation of wool fabrics more than animal glue adhesive.

The effect of ageing on fiber chemical structure

From the Fig. 6 and 7 it is clear for the reader that typical bands of wool fabrics are assigned to the peptide bond, the fundamental structural unit of the polypeptide chain on wool fabrics, were visible on FTIR spectra. Furthermore, FTIR spectroscopy shows the changes in chemical structure of the treated wool fabrics by using animal glue and nano 
glue adhesive under artificial thermal ageing were assessed by ATR-FTIR spectroscopy. The FTIR spectroscopy is including difference spectra obtained by subtracting the spectrum of a control wool sample from the spectrum of the thermally aged samples. By other words, the absorption spectra of wool fabric by using Fourier-transform infrared spectroscopy show characteristic absorption bands of the peptide bonds (-CONH-) that establish different bands that are known as the strong amide I, amide II, and amide III. One can notice that the amide I is very useful to investigate the secondary structure of the wool proteins that is mainly related with the $\mathrm{C}=\mathrm{O}$ stretching and it appears in the range of $1700-1600 \mathrm{~cm}^{-1}$ of spectra. On the other side, the amide II, that appear in $1540-1520 \mathrm{~cm}^{-1}$ range, is related to the $\mathrm{C}-\mathrm{N}$ stretching and $\mathrm{N}-\mathrm{H}$ bending vibration. While, the amide III occurs in the range of 1430-1450 $\mathrm{cm}^{-1}$, and it results from $\mathrm{C}-\mathrm{H}$ bending vibration. In addition, the positions of these bands indicate the conformations of the protein materials: $1650 \mathrm{~cm}^{-1}$ (random coil) and $1630 \mathrm{~cm}^{-1}(\beta-$ sheet) for amide I, $1540 \mathrm{~cm}^{-1}$ (random coil) and $1520 \mathrm{~cm}^{-1}$ ( $\beta$ - sheet) for amide II. By noticing Fig. 6 and 7 the results are showed that all the amide I and amide II occured respectively at $\approx 1620 \mathrm{~cm}^{-1}$ and $\approx 1513 \mathrm{~cm}^{-1}$ indicating that all the wool samples present mainly in $\beta$ - sheet structure. One can see that ageing make a slight hydrolysis of the polypeptide chain that is apparent as an increase in the $\mathrm{OH}$ stretching or bending frequencies found at $\approx 3400$ and $\approx 1650 \mathrm{~cm}-1$ [33-34].

The result referee that the treated wool fabrics without ageing show the bands associated with the peptide bonds were well resolved and possessed high intensity. For the same treated wool, fabrics after ageing the position of the amide bands did slight change and slight change in their intensity was observed. Also, it is noticed increasing of the reduction in the density of different amide

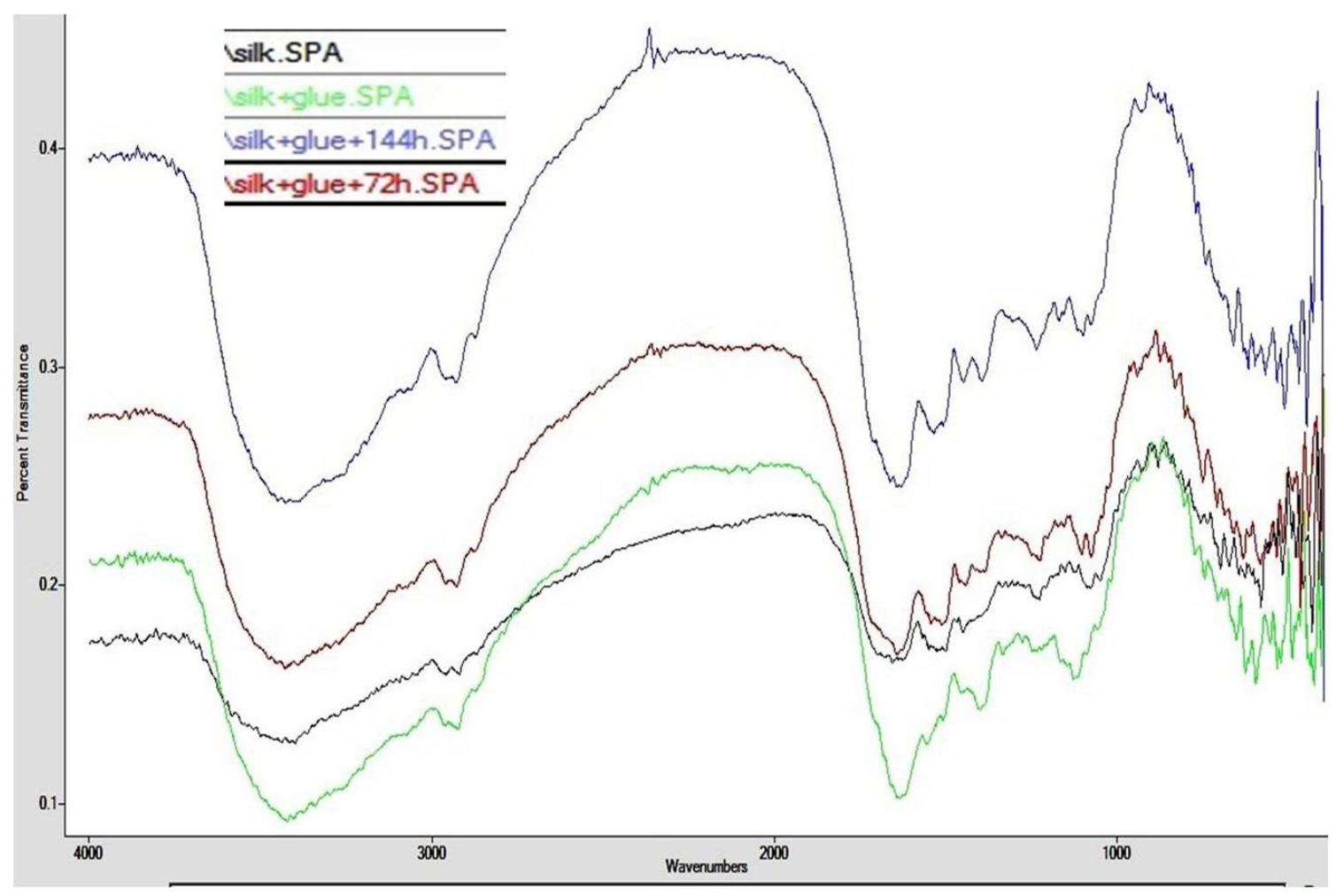

Fig. 6. FTIR of wool dyed with safflower mordanted by alum (black color), and FTIR FTIR of wool dyed with safflower mordanted by alum treated with animal glue adhesive after ageing for $144 \mathrm{~h}$. 


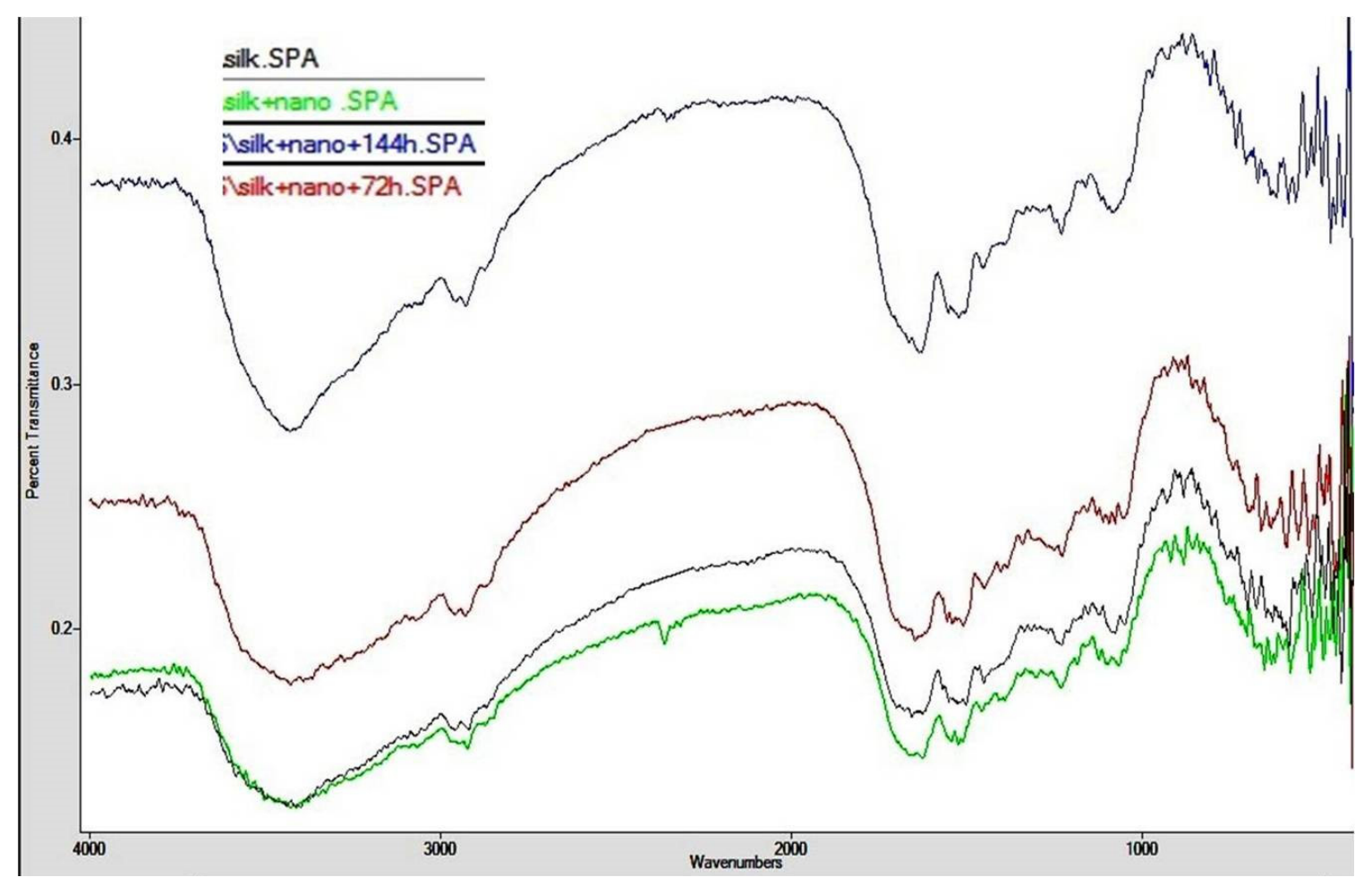

Fig. 7. FTIR of wool dyed with safflower mordanted by alum (black color), and FTIR FTIR of wool dyed with safflower mordanted by alum treated with Nano animal glue adhesive after ageing for $144 \mathrm{~h}$.

bands were observed when increasing the ageing time and ageing intensity.

\section{Conclusion}

This research provided interesting result of using Nano glue adhesive. These results of this work are confirmed that the nano glue adhesive enhances the durability of surface morphology of sample against the thermal deterioration. Furthermore, there are no noticeable changes in the color of treated wool textile by nano glue adhesive samples before and after the thermal ageing. FTIR shows that there are new characteristic bands due to application by animal glue adhesive and Nano glue adhesive. By this study, it is clear that Nano glue adhesive is suitable for conservation of wool fabrics more than animal glue adhesive. The next step of this work that applying Nano animal glue adhesive in order to conserve and consolidate the fragile textiles in the museum.

\section{References}

1. Hillyer L. and Tinker Z., Evaluating the use of adhesives in textile conservation: Part I: An overview and surveys of current use. The Conservator 21(1), 37-47 (1997).
2. Horie, C. V. Materials for Conservation: Organic Consolidants, Adhesives and Coatings, Routledge

3. Hassan R.B.A. and Mohamed, W.S., Effect of Methylmrthacrylate/Hydroxyethyl Methacrylate copolymer on optical and mechanical properties and long term durability of paper under accelerated ageing, International Journal of Conservation Science, 8(2), 237-250 (2017).

4. Mansour M., Hassan R. and Salem M., Characterization of historical bookbinding leather by FTIR, SEM -EDX and investigation of fungal species isolated from the leather, Egyptian Journal of Archaeological \& Restoration Studies, 7(1), 1-10 (2017)

5. Pretzel B., Evaluating the use of adhesives in textile conservation Part II: Tests and evaluation matrix. The Conservator 21(1), 48-58 (1997).

6. Ragauskienė D. and Makuška R., Consolidation and ageing features of vinylneodecanoate containing in adhesive films used as a support for museum textiles. Chemija 17(2-3), 52-59 (2006).

7. Ahmed H. E. and Kolisis F. N., An investigation into the removal of starch paste adhesives from historical textiles by using the enzyme $\alpha$-amylase. 
Journal of Cultural Heritage 12(2), 169-179 (2011).

8. Landi S., The Textile Conservator's Manual, Routledge (1998).

9. Tímár-Balázsy Á. and Eastop D., Chemical Principles of Textile Conservation, Routledge. (1998).

10. Schellmann N. C., Animal glues: a review of their key properties relevant to conservation. Studies in Conservation 52(sup1), 55-66 (2007).

11. Ahmed H. E. and Kolisis F. N., A study on using of protease for removal of animal glue adhesive in textile conservation. Journal of Applied Polymer Science 124(5), 3565-3576 (2012).

12. Ahmed H. E. and Ziddan Y. E.,. A new approach for conservation treatment of a silk textile in Islamic Art Museum, Cairo. Journal of Cultural Heritage 12(4),412-419 (2011).

13. Garside P. andWyeth P., The Inherent acidic characteristics of silk, part ii-weighted silks. E-Pres. Sci 7, 126-131 (2010).

14. Leene J. E. and Demeny L., Artificial ageing of yarns in presence as well as in absence of light and under different atmospheric conditions (1972).

15. Osman E. M. and Michael M. N., The effect of both UV $\backslash$ Ozone and chitosan on natural fabrics. International Journal of Chemistry 2(2), 28 (2010).

16. Bechtold T. and Turcanu A., Natural dyes in modern textile dyehouses-how to combine experiences of two centuries to meet the demands of the future? Journal of Cleaner Production 11(5), 499-509 (2003).

17. Ahmed H. E., History of Natural Dyes in North Africa 'Egypt'." Handbook of Natural Colorants: 27 (2009).

18. Schweppe H., Practical Hints on Dyeing with Natural Dyes: Production of Comparative Dyeings for the Identification of Dyes on Historic Textile Materials; [15th Through 19th September 1986], Smithsonian Institution(1986).

19. Schweppe H., Practical information for the identification of dyes on historic textile materials. (1988).

20. Coester C. and Langer K.., Gelatin nanoparticles by two step desolvation a new preparation method, surface modifications and cell uptake. Journal of
Microencapsulation1 7(2),187-193 (2000).

21. Feller R., Accelerated Aging: Photochemical and Thermal Aspects: Marina del Rey, The Getty Conservation Institute. Ann Arbor: Edwards Bros (1994).

22. Bégin P. L. and Kaminska E., Thermal accelerated ageing test method development. Restaurator 23(2), 89-105(2002).

23. Kuruppillai R. and S., Degradation of silk by heat and light. Historic textile and paper materials: conservation and characterization, American Chemical Society: 111,127 (1986).

24. Batcheller J. C., Optical and scanning electron microscopy techniques for the determination of hair fibres from Romano-Egyptian textiles. Scientific analysis of ancient and historic textiles: informing preservation, display and interpretation: postprints, First annual conference, 13-15 July Archetype Publications. (2004).

25. Rood A. and Streeter R., Size distributions of occupational airborne asbestos textile fibres as determined by transmission electron microscopy. Annals of Occupational Hygiene 28(3), 333-339 (1984).

26. Xiao X. and Wang Y., Emulsion copolymerization of fluorinated acrylate in the presence of a polymerizable emulsifier. Colloids and Surfaces A: Physicochemical and Engineering Aspects 348(1), 151-156 (2009).

27. Booth J. E, Principles Of Textile Testing. (1969).

28. Berns R. and Billmeyer F., Measuring color."Billmeyer and Saltzman principles of color technology. New York: John Wiley: 75,105, (2000).

29. Wyszecki G. and Stiles W., Color Science, New York (et al.). London and Sydney: John Wiley(2000).

30. Standard, A., Annual book of ASTM standards. American Society for Testing and Materials Annual, Philadelphia, PA, USA 4(04.08) (2004).

31. Baker M. and Van der Reyden D., FTIR Analysis of Coated Papers. The Books and paper Group annual 9 (1989).

32. Derrick M., Fourier transform infrared spectral analysis of natural resins used in furniture finishes. 
Journal of the American Institute for Conservation 28(1), 43-56 (1989).

33. Derrick M., Evaluation of the State of Degradation of Dead Sea Scroll Samples Using FT-IR Spectroscopy. Book and Paper Group Annual, The American Institute for Conservation 10, 45-65 (1991).
34. Broda J., Przybyło S., Kobiela-Mendrek K., Binia. D., Rom M., Grzybowska-Pietras J., and Laszczak R., Biodegradation of sheep wool geotextiles. International Biodeterioration \& Biodegradation1 15, 31-38 (2016).

(Received 27 / 9 / 2017) accepted $20 / 11 / 2017)$

\title{
سلوك تلف لاصق الغراء في حجم النانو وذلاك لأعمال ترميم وصيانة المنسوجات التاريخية

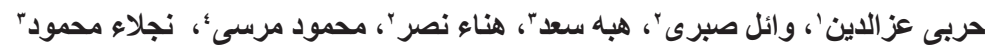

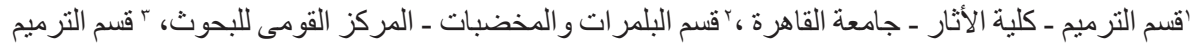

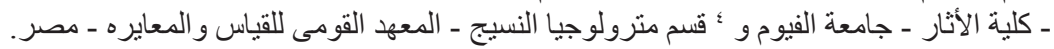

\begin{abstract}
تتعرض المنسوجات التاريخية لعمليات تلف مختلفة مثل التلف البيولوجي بأنواعه و الظروف البيئة المختلفة

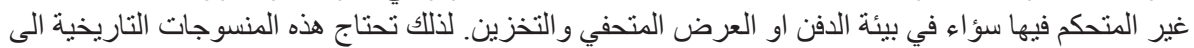

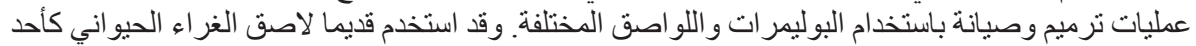

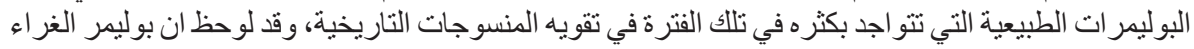

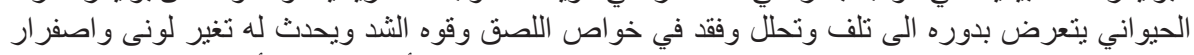

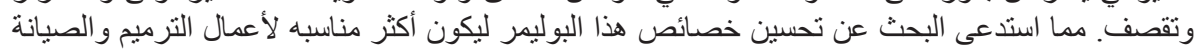

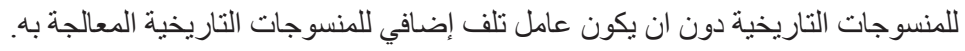

ركزت هذه الدراسة على انتاج لاصق غراء حيو اني في حجم النانو وقياس الحجم النانو للبوليمر قبل

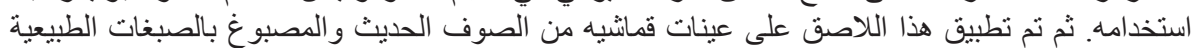

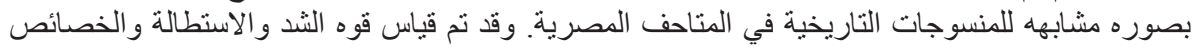

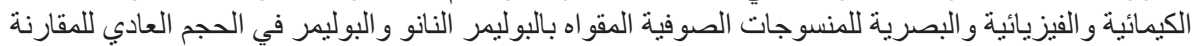

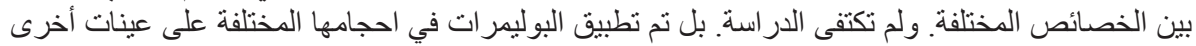

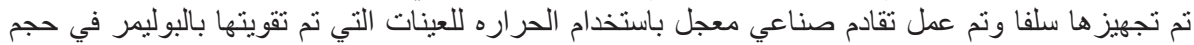

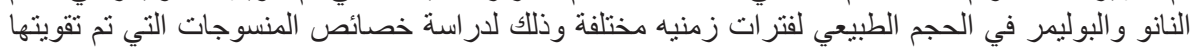
بالبوليمر ات على الَّدى الزمنى البعيد.

وقد اعتمدت الدراسة أساليب علميه عديده للفحوص و التحاليل للبوليمر في حجم النانو و البوليمر الطبيعي

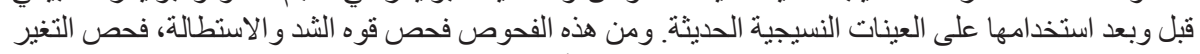

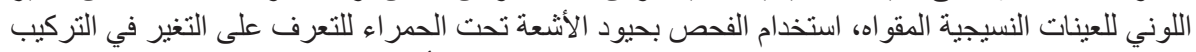

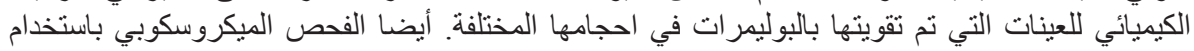

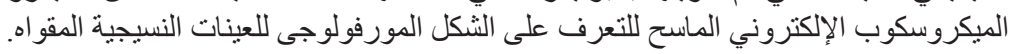

وقد اثتتت الدر اسة بدرجه واضحة ان بوليمر الغر اء الحيو اني في الحجم النانو كان أكثر فاعليه وكفاءه من

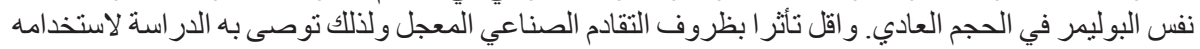
في تقويه المنسوجات التاريخية الضعيفة والتي تحتاج الى تدخل بالعلاج و الترميم و الصيانة.
\end{abstract}

